\title{
CLINICAL SPECTRUM OF MUCOCUTANEOUS MANIFESTATIONS IN PATIENTS WITH HUMAN IMMUNODEFICIENCY VIRUS INFECTION REFERRED TO A DERMATOLOGIST
}

\author{
Abhilasha Williams ${ }^{1}$, Jency Maria Koshy², Clarence J. Samuel ${ }^{3}$ \\ ${ }^{1}$ Associate Professor, Department of Dermatology, Christian Medical College and Hospital, Ludhiana. \\ ${ }^{2}$ Associate Professor, Department of Medicine, Christian Medical College and Hospital, Ludhiana. \\ ${ }^{3}$ Associate Professor, Department of Community Medicine, Christian Medical College and Hospital, Ludhiana.
}

ABSTRACT
BACKGROUND
In today's era of HIV pandemic, it is vital for the physician and the dermatologist to be aware of the wide spectrum of cutaneous
manifestations of HIV, as they could be one of the earliest indicators of retroviral illness warranting a prompt diagnosis and early
initiation of antiretro viral therapy.

\section{AIMS}

To study the mucocutaneous manifestations of HIV and correlate it with CD4 counts.

\section{SETTINGS AND DESIGN}

All the HIV positive patients referred from an HIV physician to a dermatologist for screening of mucocutaneous manifestations of HIV were included for a period of 6 months.

\section{MATERIALS AND METHOD}

The anonymised records of 36 patients were accessed for relevant demographical and dermatological data including details of ART and the CD4 counts within the last 6 months.

\section{STATISTICAL ANALYSIS USED}

The data was collated on Microsoft Excel 2010 and was analysed using SPSS version 21. Descriptive statistics included frequencies, proportions and Chi sq. test.

\section{RESULTS}

There were 24 males (66.7\%) and 12 females (33.3\%). The mean CD4 counts were 237 cells/ $/ \mathrm{mm}^{3}$. The common mucocutaneous manifestations of HIV were oral candidiasis (58.3\%), seborrhoeic dermatitis (30.6\%), generalised xerosis (25\%), longitudinal melanonychia and dermatophytosis (16.7\%), bacterial infections and brittle nails (13.9\%) and onychomycosis $(11.1 \%)$. The other less common manifestations were pruritic papular eruptions of HIV (8.3\%), koilonychia, paronychia, lichen planus, acquired ichthyosis and shiny nails (5.6\%). Oral candidiasis was noted to be more common in men than in women. The CD4 counts decreased as the HIV clinical staging increased.

\section{CONCLUSIONS}

Certain dermatoses tend to occur more commonly in an HIV infected patient. The mucocutaneous manifestations of HIV often correlate with the CD4 counts and in a resource limited health setup help to judge the immune status of an HIV patient, prompting early initiation of ART which decrease morbidity and mortality and improve the quality of life of these patients.

\section{KEYWORDS}

Mucocutaneous Manifestations of HIV, Oral Candidiasis, Seborrhoeic Dermatitis, CD4 Counts.

HOW TO CITE THIS ARTICLE: Abhilasha Williams, Jency Maria Koshy, Clarence J. Samuel. "Clinical Spectrum of Mucocutaneous Manifestations in Patients with Human Immunodeficiency Virus Infection Referred to A Dermatologist." Journal of Evolution of Medical and Dental Sciences 2015; Vol. 4, Issue 100, December 14; Page: 16490-16494, D0I: 10.14260/jemds/2015/2450

\section{INTRODUCTION}

The majority of the patients infected with Human Immunodeficiency Virus (HIV) pandemic are from developing countries. According to WHO, the total number of adults above 15 years of age living with HIV in 2013 was 1,900,000.(1) The cutaneous manifestations of HIV are well known.

Approximately, $90 \%$ of the HIV positive patients develop

Financial or Other, Competing Interest: None.

Submission 24-11-2015, Peer Review 25-11-2015,

Acceptance 08-12-2015, Published 11-12-2015.

Corresponding Author:

Dr. Abhilasha Williams,

Department of Dermatology,

CMC \& Hospital, Ludhiana, Punjab.

E-mail: abhilasha.williams@gmail.com

DOI:10.14260/jemds/2015/2450 cutaneous manifestations during the natural course of illness.(2)

In today's era of HIV pandemic, it is vital for the physician and the dermatologist to be aware of the wide spectrum of cutaneous manifestations of HIV, which could be as common as oral candidiasis to as rare as Kaposi's sarcoma in an Indian setting. Mucocutaneous manifestations could be one of the earliest indicators of retroviral illness warranting a prompt diagnosis and early initiation of Anti-Retro Viral Therapy (ART).

Skin is the largest organ of the body and the common dermatosis could be easily classified under natural sunlight without the need of highly specialised equipment.

The mucocutaneous manifestations of HIV can be classified as infectious, non-infectious and neoplastic dermatoses. The commonest infections which plague HIV infected individuals include MRSA infections, Herpes Simplex 
Virus infections, Human Papilloma Virus infections and Syphilis to name a few.(3) Kaposi's sarcoma, lymphomas and squamous cell carcinomas are the common neoplastic dermatoses.

The frequently noted primary non-infectious dermatoses affecting the HIV-type1 infected individuals include seborrhoeic dermatitis, psoriasis and atopic dermatitis.(4) Therefore, it is prudent for all the medical health professionals to be sensitised to these common dermatoses, especially in a resource poor setting where they could help in assessing the immune status of these patients if the facility for doing the CD 4 counts is not available.

\section{METHODS}

In this case series, all the HIV positive patients referred from an HIV physician to a dermatologist for screening of mucocutaneous manifestations of HIV were included from September 2014 till February 2015. The anonymised records were accessed for relevant demographical and dermatological data including details of ART and CD4 counts within the last 6 months which were noted on a pro forma. The data was collated on Microsoft Excel 2010 and was analysed using SPSS version 21. Descriptive statistics included frequencies, proportions and Chi sq. test. $\mathrm{P}$ value $<0.05$ was considered clinically significant.

\section{RESULTS}

Of the 36 HIV positive patients studied, there were 24 males $(66.7 \%)$ and 12 females (33.3\%). The mean age was 41.1 years (SD \pm 11.5 years). Sixteen patients were on ART. The CD4 counts were available for 32 patients. The mean CD4 counts were 237 cells $/ \mathrm{mm}^{3}$ The commonest mucocutaneous manifestation of HIV was oral candidiasis found in 58.3\% of the cohort. The second most common cutaneous disorder was seborrhoeic dermatitis (30.6\%) followed by generalised xerosis noted in $25 \%$ of the study group.

The other frequently diagnosed dermatosis included longitudinal melanonychia and dermatophytosis in $16.7 \%$, bacterial infections and brittle nails in $13.9 \%$ and onychomycosis in $11.1 \%$ of the study group. Of the other less common manifestations seen in this study group were pruritic papular eruptions of HIV in $8.3 \%$ of the patients. Koilonychia paronychia, lichen planus, acquired ichthyosis and shiny nails were present in $5.6 \%$ of the patients. Oral candidiasis was also noted to be more common in men than in women. $(\mathrm{P}$ value $=0.031)($ Table: 1$)$.

The commonest infectious dermatosis was fungal infections occuring in $41.7 \%$ of the study group followed by Viral (19.4\%) and Bacterial infections (13.9\%). The commonest fungal infection was dermatophytosis $(16.7 \%)$ and the commonest viral infection was herpes simplex infection (11.1\%). (Table: 2). The majority of HIV positive patients with fungal infections were found in the age group of 21-40 years. Bacterial infections and generalised xerosis were more common in the age group of 41-60 years. (Table: 3 ).

There was significant increase in prevalence of oral candidiasis in WHO clinical stage 3 and 4 (p value 0.025 ) and with decreasing CD4 counts. (P value 0.023) (Tables: 4 and 5). There was also an indirect correlation between prevalence of oral candidiasis and worsening CD4 counts.

Oral candidiasis was more prevalent in those patients, who had CD4 counts $<50$ cells $/ \mathrm{mm}^{3}$ ( $\mathrm{P}$ value=0.023). Seborrhoeic dermatitis was more prevalent in patients with CD4 counts $>350$ cells $/ \mathrm{mm}^{3}$ The common dermatological manifestations which were more common in patients with CD4 counts <50cells/ in our study included herpes genitalis, molluscum contagiosum, fungal infections of the skin and haemorrhoids. (Table: 5).

On correlating the HIV clinical staging and the CD4 counts, we found that the CD4 counts decreased as the HIV clinical staging increased. (P value=0.067) (Table: 6) In our study, majority of the patients who were on ART were found to be in WHO clinical stage 1 . (P value $=0.043$ ) (Table: 7) This could be explained on the fact that the WHO clinical stage improved once the patient was started on ART. In our study, the majority of the patients on ART were found to have CD4 counts between 101-200cells/.

The fact that 8 out of 11 patients with CD4 counts $<100$ cells/ were not on ART, could be explained on the fact that they were newly diagnosed to have HIV infection at the time of the referral to the dermatologist. (Table: 8) There was no correlation between the WHO clinical staging, CD4 counts, ART and gender, highlighting the fact that ART is considered as a treatment option based on the clinical manifestations and immune status rather than the gender. (Tables: 8 and 9).

\begin{tabular}{|c|c|c|c|c|c|}
\hline $\begin{array}{c}\text { Dermatological } \\
\text { Manifestations }\end{array}$ & $\begin{array}{c}\text { Male } \\
\mathbf{( 2 4 )}\end{array}$ & $\begin{array}{c}\text { Female } \\
\text { (12) }\end{array}$ & $\begin{array}{c}\text { Total } \\
\text { (Percentage) }\end{array}$ & Chi sq & $\begin{array}{c}\text { P } \\
\text { value }\end{array}$ \\
\hline Oral candidiasis & 17 & 4 & $21(58.3)$ & 4.629 & 0.031 \\
\hline Seborrhoeic dermatitis & 5 & 6 & $11(30.6)$ & 3.207 & 0.073 \\
\hline Generalized xerosis & 4 & 5 & $9(25)$ & 2.667 & 0.102 \\
\hline Viral infections & 5 & 2 & $7(19.4)$ & 0.08 & 0.4 \\
\hline Longitudinal Melanonychia & 4 & 2 & $6(16.7)$ & 0.0 & 1 \\
\hline Dermatophytosis & 3 & 3 & $6(16.7)$ & 0.9 & 0.343 \\
\hline Bacterial infections & 4 & 1 & $5(13.9)$ & 0.465 & 0.496 \\
\hline Brittle nails & 2 & 3 & $5(13.9)$ & 1.858 & 0.173 \\
\hline Onycomycosis & 4 & 0 & $4(11.1)$ & 2.25 & 0.134 \\
\hline Others & 21 & 12 & $33(91.7)$ & 2.16 & 0.10 \\
\hline Table 1: Gender Distribution of Common Mucocutaneous Manifestations \\
\hline
\end{tabular}




\begin{tabular}{|c|c|c|}
\hline \multirow{4}{*}{$\begin{array}{c}\text { Type of } \\
\text { Infection }\end{array}$} & $\begin{array}{c}\text { Dermatological } \\
\text { Manifestation }\end{array}$ & Total (\%) \\
\hline \multirow{5}{*}{} & Dermatophytosis & $6(16.7)$ \\
\cline { 2 - 3 } & Onychomycosis & $4(11.1)$ \\
\cline { 2 - 3 } & Paronychia & $2(5.6)$ \\
\cline { 2 - 3 } & Anguar chelitis & $1(2.8)$ \\
\cline { 2 - 3 } & Pityriasis versicolor & $1(2.8)$ \\
\cline { 2 - 3 } & Genital candidiasis & $1(2.8)$ \\
\cline { 2 - 3 } & Total & $\mathbf{1 5 ( 4 1 . 7 )}$ \\
\cline { 2 - 3 } & Herpes labialis & $2(5.6)$ \\
\cline { 2 - 3 } & Herpes genitalis & $2(5.6)$ \\
\cline { 2 - 3 } & Herpes zoster & $1(2.8)$ \\
\cline { 2 - 3 } & Mollucum cantagiosum & $1(2.8)$ \\
\cline { 2 - 3 } & Genital warts & $1(2.8)$ \\
\cline { 2 - 3 } & Total & $\mathbf{7 ( 1 9 . 4 )}$ \\
\cline { 2 - 3 } & Ecthyma & $2(5.6)$ \\
\cline { 2 - 3 } & Folliculitis & $2(5.6)$ \\
\cline { 2 - 3 } & Cellulitis & $1(2.8)$ \\
\cline { 2 - 3 } & Total & $\mathbf{5 ( 1 3 . 9 )}$ \\
\hline \multirow{5}{*}{ BACTERIAL } & \\
\hline & Table 2: Clinical Spectrum of Infective Dermatosis \\
\hline
\end{tabular}

* Each patient may have more than one infection

\begin{tabular}{|c|c|c|c|c|c|c|c|}
\hline \multirow{2}{*}{\multicolumn{2}{|c|}{$\begin{array}{l}\text { Dermatological } \\
\text { Manifestations }\end{array}$}} & \multicolumn{4}{|c|}{ AGE GROUPS (Years) } & \multirow{3}{*}{$\begin{array}{c}\text { Chi sq } \\
1.920\end{array}$} & \multirow{3}{*}{$\begin{array}{c}\begin{array}{c}P \\
\text { value }\end{array} \\
0.589\end{array}$} \\
\hline & & \multirow{2}{*}{$\begin{array}{c}\begin{array}{c}0-20 \\
(n=)\end{array} \\
1 \\
\end{array}$} & \multirow{2}{*}{$\begin{array}{c}\begin{array}{c}21-40 \\
(\mathbf{n}=)\end{array} \\
11\end{array}$} & \multirow{2}{*}{$\begin{array}{c}\begin{array}{r}41-60 \\
(n=)\end{array} \\
8\end{array}$} & \multirow{2}{*}{$\begin{array}{c}\begin{array}{c}61-80 \\
(\mathbf{n}=)\end{array} \\
1\end{array}$} & & \\
\hline Oral candidiasis & YES & & & & & & \\
\hline Seborrhoeic dermatitis & YES & 1 & 6 & 4 & 0 & 3.639 & 0.303 \\
\hline Longitudinal Melanonychia & YES & 0 & 3 & 1 & 2 & 6.240 & 0.100 \\
\hline Onychomycosis & YES & 0 & 2 & 1 & 1 & 1.744 & 0.627 \\
\hline Bacterial infections & YES & 0 & 1 & 4 & 0 & 5.760 & 0.124 \\
\hline Generalised xerosis & YES & 0 & 2 & 5 & 2 & 7.289 & 0.063 \\
\hline Dermatophytosis & YES & 0 & 4 & 2 & 0 & 0.960 & 0.811 \\
\hline Brittle nails & YES & 0 & 2 & 3 & 0 & 2.137 & 0.545 \\
\hline
\end{tabular}

\begin{tabular}{|c|c|c|c|c|c|c|c|}
\hline \multirow[b]{2}{*}{ Dermatological Manifestations } & \multicolumn{5}{|c|}{ WHO STAGING } & \multirow[b]{2}{*}{ Chi sq } & \multirow[b]{2}{*}{$P$ value } \\
\hline & & $\begin{array}{c}1 \\
(n=8)\end{array}$ & $\begin{array}{c}2 \\
(n=4)\end{array}$ & $\begin{array}{c}3 \\
(n=15)\end{array}$ & $\begin{array}{c}4 \\
(n=9)\end{array}$ & & \\
\hline Oral candidiasis & YES & 2 & 1 & 10 & 8 & 9.371 & $.025^{*}$ \\
\hline Seborrhoeic dermatitis & YES & 3 & 1 & 3 & 4 & 1.846 & .605 \\
\hline Longitudinal melanonychia & YES & 0 & 1 & 4 & 1 & 3.080 & .379 \\
\hline Onychomycosis & YES & 1 & 2 & 1 & 0 & 7.566 & .056 \\
\hline Bacterial infections & YES & 0 & 0 & 3 & 2 & 2.926 & .403 \\
\hline Generalised xerosis & YES & 2 & 0 & 5 & 2 & 1.926 & .588 \\
\hline Dermatophytosis & YES & 2 & 1 & 3 & 0 & 2.520 & .472 \\
\hline Brittle nails & YES & 1 & 1 & 1 & 2 & 1.603 & .659 \\
\hline
\end{tabular}

\begin{tabular}{|c|c|c|c|c|c|c|c|c|}
\hline \multirow{2}{*}{\multicolumn{2}{|c|}{ Dermatological Manifestations }} & \multicolumn{5}{|c|}{ CD4 Counts (cells/mm³) } & \multirow{3}{*}{$\begin{array}{l}\text { Chi sq } \\
11.375\end{array}$} & \multirow{3}{*}{$\begin{array}{l}\text { P value } \\
0.023^{* *} \\
\end{array}$} \\
\hline & & \multirow{2}{*}{$\begin{array}{c}\mathbf{5 0} \\
\mathrm{n}=\mathbf{8} \\
7 \\
\end{array}$} & \multirow{2}{*}{$\begin{array}{c}\text { 51-100 } \\
n=2 \\
0\end{array}$} & \multirow{2}{*}{$\begin{array}{c}\begin{array}{c}101-200 \\
\mathbf{n}=10\end{array} \\
8 \\
\end{array}$} & \multirow{2}{*}{$\begin{array}{c}\begin{array}{c}201-350 \\
n=4\end{array} \\
2 \\
\end{array}$} & \multirow{2}{*}{$\begin{array}{c}\begin{array}{c}\mathbf{3 5 0} \\
\mathbf{n}=\mathbf{8}\end{array} \\
2\end{array}$} & & \\
\hline Oral candidiasis & YES & & & & & & & \\
\hline Seborrhoeic dermatitis & YES & 1 & 1 & 3 & 0 & 4 & 4.916 & 0.296 \\
\hline Longitudinal Melanonychia & YES & 3 & 0 & 0 & 2 & 1 & 7.385 & 0.117 \\
\hline Onychomycosis & YES & 1 & 0 & 1 & 0 & 2 & 2.057 & 0.725 \\
\hline Bacterial infections & YES & 1 & 0 & 2 & 1 & 0 & 2.514 & 0.642 \\
\hline Generalised xerosis & YES & 2 & 1 & 3 & 1 & 1 & 1.467 & 0.833 \\
\hline Dermatophytosis & YES & 2 & 0 & 1 & 0 & 2 & 2.418 & 0.659 \\
\hline Brittle nails & YES & 0 & 0 & 1 & 1 & 2 & 3.200 & 0.525 \\
\hline
\end{tabular}




\begin{tabular}{|c|c|c|c|c|c|c|}
\hline \multirow{2}{*}{$\begin{array}{c}\text { CD4 } \\
\text { Counts(cells } / \mathrm{mm}^{3} \text { ) }\end{array}$} & \multicolumn{4}{|c|}{$\begin{array}{l}\text { WHO Clinical } \\
\text { staging }\end{array}$} & Chi sq & $\begin{array}{c}P \\
\text { value }\end{array}$ \\
\hline & 1 & 2 & 3 & 4 & \multirow{6}{*}{20.000} & \multirow{6}{*}{0.067} \\
\hline$<50$ & 0 & 0 & 5 & 3 & & \\
\hline $51-100$ & 0 & 0 & 1 & 1 & & \\
\hline $101-200$ & 1 & 2 & 4 & 3 & & \\
\hline $201-350$ & 1 & 0 & 3 & 0 & & \\
\hline$>350$ & 5 & 2 & 1 & 0 & & \\
\hline \multicolumn{7}{|c|}{$\begin{array}{c}\text { Table 6: Correlation between the CD4 } \\
\text { counts and WHO Clinical Staging }\end{array}$} \\
\hline
\end{tabular}

\begin{tabular}{|c|c|c|c|c|c|c|}
\hline & \multicolumn{7}{|c|}{ WHO Clinical Staging } & Chi sq & P value \\
\hline ART & 1 & 2 & 3 & 4 & & \multirow{2}{*}{$0.043^{*}$} \\
YES & 6 & 3 & 3 & 4 & \multirow{2}{*}{8.168} & \\
\hline NO & 2 & 1 & 12 & 5 & & \\
\hline \multicolumn{1}{|c|}{ Table 7: Correlation between WHO Staging and ART } \\
\hline
\end{tabular}

\begin{tabular}{|c|c|c|c|c|c|}
\hline & \multicolumn{2}{|c|}{ ART } & \multirow{2}{*}{ Chi sq } & \multirow{2}{*}{$P$ value } \\
\hline & & Yes & No & & \\
\hline \multirow{5}{*}{$\begin{array}{l}\text { CD4 counts } \\
\text { (cells } / \mathrm{mm}^{3} \text { ) }\end{array}$} & $<50$ & 1 & 7 & \multirow{5}{*}{5.994} & \multirow{5}{*}{0.200} \\
\hline & $50-100$ & 1 & 1 & & \\
\hline & $101-200$ & 6 & 4 & & \\
\hline & $201-350$ & 1 & 3 & & \\
\hline & $>350$ & 5 & 3 & & \\
\hline \multirow{2}{*}{ Gender } & Male & 9 & 15 & \multirow{2}{*}{1.406} & \multirow{2}{*}{0.236} \\
\hline & Female & 7 & 5 & & \\
\hline
\end{tabular}

\begin{tabular}{|c|c|c|c|c|c|}
\hline & \multicolumn{2}{|c|}{ Gender } & \multirow{2}{*}{$\begin{array}{c}\text { Chi } \\
\text { sq }\end{array}$} & \multirow{2}{*}{$\begin{array}{c}P \\
\text { value }\end{array}$} \\
\hline & & $\begin{array}{c}\text { Mal } \\
\text { e }\end{array}$ & Female & & \\
\hline \multirow{4}{*}{$\begin{array}{l}\text { WHO } \\
\text { Clinical } \\
\text { Staging }\end{array}$} & 1 & 4 & 4 & \multirow{4}{*}{1.425} & \multirow{4}{*}{0.700} \\
\hline & 2 & 3 & 1 & & \\
\hline & 3 & 11 & 4 & & \\
\hline & 4 & 6 & 3 & & \\
\hline \multirow{5}{*}{$\begin{array}{c}\text { CD4 } \\
\text { Counts } \\
\text { (cells/mm } \\
\text { 3) }\end{array}$} & $<50$ & 6 & 2 & \multirow{5}{*}{4.405} & \multirow{5}{*}{0.354} \\
\hline & $50-100$ & 1 & 1 & & \\
\hline & $101-200$ & 8 & 2 & & \\
\hline & $201-350$ & 3 & 1 & & \\
\hline & $>350$ & 3 & 5 & & \\
\hline
\end{tabular}

Table 9: Correlation of Gender with WHO Clinical Staging and CD4 Counts

\section{DISCUSSION}

Skin manifestations are the presenting symptom of HIV infection in approximately $39.3 \%$ of the patients.(5) The commonest mucocutaneous manifestation in our study was oral candidiasis (58.3\%), followed by dermatophytosis $(16.7 \%)$ and seborrhoeic dermatitis (11\%), which is similar to the study done by Attili et al.(5) However, drug induced cutaneous reactions were not observed in our study.

Among the cutaneous infections commonly associated with HIV, we found that the majority of the patients suffered from a spectrum of fungal infections \{dermatophytosis $(16.7 \%)$, onychomycosis (11.1\%), paronychia (5.6\%), angular chelitis $(2.8 \%)$ \} similar to the study done by Vasudevan et al.(6) Next to follow were viral infections in $19.4 \%$ and bacterial infections in $13.9 \%$ of our study group.

According to Munoz-Perez et al. certain dermatoses correlate well with disease progression due to their strong association with CD4 counts like herpes genitalis, herpes simplex infection, molluscum contagiosum, common warts, PPE and seborrhoeic dermatitis.(7) Our results corroborate their findings.

On correlating the mucocutaneous manifestations with CD4 counts, it was found that there was a negative association between the two. As the CD4 counts decreased, the prevalence of oral candidiasis was noted to be higher, similar to the study done by Attili et al.(5) It is also known that infectious mucocutaneous manifestations occur when the CD4 counts fall below 200 cells $/ \mathrm{mm}^{3}$, whereas non-infectious dermatosis like seborrhoeic dermatitis are more prevalent when the CD4

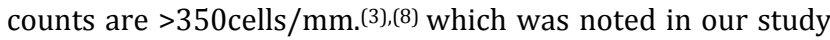
too.

The commonest non-infectious dermatoses noted in our study were seborrhoeic dermatitis $(30.6 \%)$ and generalised xerosis $(25 \%)$. Singh et al. had reported xerosis in $52.5 \%$ of their study population and seborrhoeic dermatits in $74.16 \% .{ }^{(9)}$ The prevalence of pruritic papular eruptions in our study was $8.3 \%$, whereas other studies report a prevalence ranging from $7.7 \%$ to $35.8 \% .^{(9-11)}$

We observed longitudinal melanonychia in $16.7 \%$ of the patients similar to that reported by Cribier et al.(11) whereas Kore et al. reported nail discoloration in $5.4 \%$ of their study population.(12)

We also noted that when there was a decrease in the CD4 counts, the patient tended to be in a higher HIV clinical staging, consistent with other studies.(13) This re-emphasizes the importance of clinical assessment of the patient to know the underlying immune status even in resource limited setting where the monitoring of CD4 counts is not possible.

In our study, the dermatoses tending to be more common in patients with $\mathrm{CD} 4$ counts $<50$ cells $/ \mathrm{mm}^{3}$ included herpes genitalis, molluscum contagiosum and fungal infections of the skin. Kaposi's sarcoma, cutaneous cryptococcosis, bacillary angiomatosis, proximal onychomycosis which are considered AIDS defining illnesses were absent in our study population stressing the fact that the spectrum of cutaneous manifestations in India vary from those seen in the west.(6)(14) Oral hairy leukoplakia was not observed in our study.

\section{CONCLUSION}

It is important for the physician and the dermatologist to be aware of the mucocutaneous manifestations of HIV, especially oral candidiasis which is its most common mucocutaneous manifestation. Dermatologists should be aware of the various presentations of oral candidiasis so as to screen them for HIV infection early in the course of the disease, leading to prompt diagnosis and referrals to the Infectious Disease physician.

This case series further emphasises the fact that there are certain dermatoses, which tend to occur more commonly in an HIV infected patient. The mucocutaneous manifestations of HIV often correlate with the CD4 counts and in a resource limited health setup, it is possible to judge the immune status of an HIV patient based on this. The early initiation of ART decrease morbidity and mortality and improve the quality of life of these patients.

\section{BIBLIOGRAPHY}

1. Global Health Observatory Data Repository [Internet]. WHO. [cited 2015 Nov 5]. Available from: http://apps.who.int/gho/data/node.main. 621?lang=en.

2. Coldiron BM, Bergstresser PR. Prevalence and clinical spectrum of skin disease in patients infected with human immunodeficiency virus. Arch Dermatol. 1989 Mar;125(3):357-61.

3. Rodgers S, Leslie KS. Skin infections in HIV-infected individuals in the era of HAART. Curr Opin Infect Dis. 2011 Apr;24(2):124-9.

4. Cedeno-Laurent F, Gómez-Flores M, Mendez N, AncerRodríguez J, Bryant JL, Gaspari AA, et al. New insights into HIV-1-primary skin disorders. J Int AIDS Soc. 2011 Jan 24;14:5. 
5. Attili VSS, Singh VP, Sundar S, Gulati AK, Varma DK, Rai M. Relationship between skin diseases and CD4 cell count in a hospital based cohort of HIV infected adults in North India. Journal, Indian Academy of Clinical Medicine (JIACM). 2008;9(1):20-5.

6. Vasudevan B, Sagar A, Bahal A, Mohanty AP. Cutaneous manifestations of HIV-a detailed study of morphological variants, markers of advanced disease, and the changing spectrum. Med J Armed Forces India. 2012 Jan 1;68(1):20-7.

7. Muñoz-Pérez MA, Rodriguez-Pichardo A, Camacho F, Colmenero MA. Dermatological findings correlated with CD4 lymphocyte counts in a prospective 3 year study of 1161 patients with human immunodeficiency virus disease predominantly acquired through intravenous drug abuse. Br J Dermatol. 1998 Jul;139(1):33-9.

8. Chawhan SM, Bhat DM, Solanke SM. Dermatological manifestations in human immunodeficiency virus infected patients: Morphological spectrum with CD4 correlation. Indian J Sex Transm Dis. 2013;34(2):89-94.
9. Singh H, Singh P, Tiwari P, Dey V, Dulhani N, Singh A. Dermatological manifestations in HIV-infected patients at a Tertiary Care Hospital in a tribal (Bastar) region of Chhattisgarh, India. Indian J Derm. 2009; 54(4):338-41.

10. Marfatia Y, Sharma A, Chaudhary D, Modi M, Mistry D. Noninfectious cutaneous manifestations of HIV/AIDS. Indian J Sex Transm Dis AIDS. 2007;28(1):19.

11. Cribier B, Mena ML, Rey D, Partisani M, Fabien V, Lang $\mathrm{JM}$, et al. Nail changes in patients infected with human immunodeficiency virus. A prospective controlled study. Arch Dermatol. 1998 0ct;134(10):1216-20.

12. Kanwar A, Vinay K, Wanchu A, Kore S. Pattern of mucocutaneous manifestations in human immunodeficiency virus-positive patients in North India. Indian J Sex Transm Dis AIDS. 2013;34(1):19.

13. Nnoruka EN, Chukwuka JC, Anisuiba B. Correlation of mucocutaneous manifestations of HIV/AIDS infection with CD4 counts and disease progression. Int J Dermatol. 2007 Oct;46 Suppl 2:14-8.

14. Rajagopalan B, Jacob M, George S. Skin lesions in HIVpositive and HIV-negative patients in South India. Int J Dermatol. 1996 Jul;35(7):489-92. 